\title{
Recasting \& rethinking Education 01 in South Africa: Imperatives for making education more relevant, responsive, and authentic
}

\section{Charl Wolhuter}

Edu-HRight, Faculty of Education, North-West University, Potchefstroom, South Africa

Charl.Wolhuter@nwu.ac.za

https://orcid.org/0000-0003-4602-7113

\section{Carolina Botha}

Community-based Educational Research (COMBER), North-West University, Potchefstroom, South Africa Carolina.Botha@nwu.ac.za

https://orcid.org/0000-0003-1693-5575

(Received: 12 February 2019; accepted: 29 July 2019)

\section{Abstract}

Our aim in this lead article is to establish the framework of the special issue consisting of selected papers presented at the 2018 South African Education Research Association (SAERA) Annual Conference that had as its theme "Education 01? In search of a new operating system: Making education more relevant, responsive and authentic." We begin with an overview of the societal changes defining the early 21 st century. We suggest that, in light of these changes, education praxis, education scholarship, and teacher education need to be re-designed with relevance, responsiveness, and authenticity if it is to meet the critical changes required.

Keywords: authenticity, education praxis, education scholarship, relevance, responsiveness, 21 st-century context, teacher education

\section{Introduction}

Ever since social scholar Alvin Toffler's publication, Future Shock, in 1970, it has been commonplace to assert that the contemporary world is one in which there is an increase (or alteration) in the rate of change (see, for example, Friedman, 2016). Social scientist Harari (2011, 2015, 2018) authored a trilogy of books highlighting the changes - in many cases until recently unthinkable - facing humanity. The challenges related to these changes have brought humanity to a crossroads. According to Ireland (2010) former Royal Society President Martin Rees estimates that, in the face of these changes, humankind has a fifty-fifty chance of 
surviving the present century. Martin (2006), in outlining 17 mega changes facing humanity, contends that the 21 st century is pivotal in that responses to these trends will determine whether humanity will survive as a species, so the 21 st century will be remembered in history. It is not only the future of humanity that is at stake, but also the future or survival of the planet.

Changes such as genetic programming and artificial intelligence are both excitingly promising and frightening. For every promise, there is a fearsome scenario, too. For example, while (at least for some, or on an aggregate level) unprecedented levels of affluence are brought about by the ceaseless economic growth (see Mortimer, 2015), inequality continues to increase thus polarising humanity not only in terms of financial means, but threatening political and social stability too (Piketty, 2014).

Humankind has selected education as one of the most important vehicles for meeting this (both frightening and promising) future. Judging by policy statements, education acts, and White Papers, as well as allocations of public budgets to education and public discourse, it seems that 20th-century humanity has paid heed to the maxim of historian and popular writer H. G. Wells that "more and more the future of humanity appears to be a race between education and catastrophe" (cited in Kirche, 2015, n.p.). Brezinka (1981) wrote almost 40 years ago that "when someone wants to do something for peace, he introduces "peace education', the person wanting to reduce the number of traffic accidents recommends 'traffic education"' (p. 2) and so on and this is even more pertinent today (see too Lutz \& Klingholz, 2017) since education is tasked with the all-encompassing mission of addressing all that is wrong with society.

It is exactly here that a glaring inconsistency is apparent and disturbing design flaws in the vehicle become evident. Education is a notoriously conservative sector of society, showing itself and its institutions to be resistant to change. This dinosaur-like depiction of education institutions was perhaps best publicised in Benjamin's satirical book The Saber Tooth Curriculum (1939), which has assumed classical status in education because he brought to the fore in it what he saw as the obsolete and anachronistic features of institutions of education. This accusation is as pertinent today as it was 80 years ago; a very cursory glance at universities will substantiate this statement. Traditional lecture theatres, with students sitting in desks or rows facing a professor behind a lectern, characterise the architecture of even those institutions regarded as leading world-class universities. The word "lecture" is derived from the Latin word lectura, a reading. Ironically, this was an arrangement predating even the invention of the printing press in the mid-15th century when the only way to duplicate literature was for the lecturer to read the text word for word, and for students to copy the text verbatim. Sadly, as mentioned above, not much has changed and the lecture is still considered to be the essence of teaching at tertiary level. In addition, the concept of summative assessment is still greatly conceptualised through traditional pen-and-paper examinations. This is so, despite the plethora of technological resources available to lecturers, the profile of the millennial student, and the imperative for more student-centred teaching and innovative assessment strategies. 
Our thesis in this article is that education in praxis in the world of today, and in South Africa in particular, with specific reference to the scholarship of education and a subject area and the education of teachers, is still stuck in obsolete and anachronistic forms. It is evident that the world, in being almost two decades into the 21 st century and undergoing seismic changes, is calling for radical renewal in many fields, including the various facets of education. We believe that society has failed to design and build an appropriate and efficient vehicle to engage with the future. The design of teacher education programmes that are meant to be the blueprint that will inform and guide education institutions in their learning and teaching brief (praxis) is clearly lacking direction and innovation. This is also reflected in the conceptualisation of scholarship in education and the cultivation of a new breed of academic and researcher in this field. To expand on the vehicle metaphor, the drivers of this vehicle are not sufficiently equipped to handle the everyday challenges they are facing. We suggest that the renewal called for in the design of this vehicle and the execution of its mission, that is, education praxis and theory as well as teacher education programmes, can be encapsulated in three words: relevance, responsiveness, and authenticity.

As the title of this lead article in this Journal of Education special issue, based on papers presented at the 2018 Annual Conference of the South African Education Research Association (SAERA), we refer to the theme of this conference: "Education 01? Making education more relevant, responsive, and authentic."

We believe that education, education scholarship, and teacher education need to be redesigned, with relevance, responsiveness, and authenticity and we describe the key changes required.

\section{The changing world of the early 21 st century}

There are a number of forceful societal trends that have an impact on education worldwide in the early 21 st century as can be seen from a literature review of works dealing with current societal trends.

The first trend has to do with the ecological crisis faced by humanity in terms of global warning and the Kyoto protocol (Friedman, 2009). The main aspects of the environmental crisis are air pollution (of which global warming is one result), the depletion and pollution of freshwater resources and the oceans, deforestation, soil erosion, and the destruction of biodiversity. This ecological crisis alone is strong enough to put at risk the survival of the human species as well as of the planet. An example of how humanity is overtaxing the stock of natural resources is that every day, according to Gribbin (2006), we all use enough water to fill a convoy of trucks lining up from the earth to the moon (482 thousand kilometres) over and above the amount of fresh water replenished by rain (mainly borehole water or groundwater). The factors behind this overexploitation of natural resources include the population explosion, the technological revolution, and growing affluence.

Throughout the past 80 years, the world has experienced a population explosion (Dorling, 2013). Although the rate of growth has slowed down remarkably in recent years and decades, 
90 million people are still added annually to the global total population, which stood at 7.7 billion in April 2019. The bulk of this growth is taking place in the countries of the Global South, making the distribution of population growth highly unequal. These differentiated growth patterns lead to changing age profiles in different parts of the world. In the countries of the Global North, the population is ageing ("greying"), while in the countries of the Global South, the population pyramid is becoming mature, that is, it is bulging in the middle age group. These differential growth patterns, together with economic and political factors, further facilitated by the communications and transport technology revolution, have resulted in a more mobile global population. A major vector of this global flow of people is from the countries of the Global South to the countries of the Global North.

The ever-advancing science and the exponential increase in technological innovations will have a significant influence on the near future, if the record of the 20th century is anything to go by (Harari, 2015). Particular areas of unabated scientific and technological progress are agricultural development and transformation, biotechnology (including genetic manipulation), the robot revolution, the information and communications technology (ICT) revolution and, lately, the looming development of artificial intelligence.

Some forceful trends on the economic front are also evident. The global economic upswing that commenced in about 1990, has proved to be one of the longest and most sustained in human history. In the ten-year period from 2005 to 2015, the global annual economic output has more than doubled from US\$29.6 trillion to US\$78.3 trillion (World Bank, 2016). According to the World Bank (2018), the growth was estimated to escalate to US\$ 80.684 trillion in 2018. At the same time, there is widespread, albeit diminishing, poverty in the world. Some 836 million people in the world survive on less than US $\$ 1.25$ per day. Although focused and successful efforts have led to a decline from the 1.923 billion people who lived in poverty in 1990 (World Bank, 2016), these statistics still present an alarming view of the real threat of poverty.

Regardless of the millions of people suffering, the neo-liberal economic revolution has, since 1990, swept to virtually every corner of the earth (Schram, 2015). This revolution entails the downscaling of the range of (economic) activities and regulations by the state and giving the forces of the free market the right of way. The global economy is becoming increasingly integrated, because of, inter alia, the communication technology revolution, the fading of the nation-state (to be discussed below), and the role of the World Bank and the International Monetary Fund. Multinational companies are becoming increasingly prominent, and a massive international financial market, which operates $24 / 7$, is evolving.

Two final economic trends are the fourth industrial revolution and the rise of knowledge economies. Whereas the first industrial revolution (from about 1750) was driven by steam power, the second (since the late 19th century) by electricity, and the third (second half of the 20th century) by digital technology, the fourth industrial revolution, currently taking shape, is characterised by a blurring of the physical, digital, and biological worlds or realities (Schwab, 2016). Scholars of history and economic development distinguish between phases in the economic development of societies. The hunter-and-gatherer economy is the most primitive 
stage. That was followed, in sequence, by an agricultural economy, an industrial economy, and a service economy. In the contemporary world, the leading economies are now evolving towards the next stage, that of a knowledge economy (Unger, 2019). A knowledge economy is defined as a space in which the production and consumption of new knowledge becomes the driving axis of the economy.

Two similarly strong sets of social trends are visible. The salience of the primary grouping (family) is declining (Williams, 2019) and secondary (workplace) grouping in society is diminishing since jobs are no longer guaranteed for life, and work from home, selfemployment, and the informal economy are all growing (World Bank, 2019), whereas that of tertiary groupings (functional groupings formed around a shared interest such as a hobby, sport, or common interest) is rising, no doubt facilitated by ICT technology.

The second set of trends relates to the rise of diverse or multicultural societies. The persistent flow of immigrants from countries in the Global South to the Global North, the modern-day Creed of Human Rights and the crumbling of the power of centralised nation-states (to be discussed below) have all contributed towards the trend. The long-standing idea of the policy of homogenisation with state imposition of one centralised sanctioned culture that excludes and suppresses the cultures of minority groups which are deemed to be a threat to its power has been superseded by the policy of multiculturalism in which positive recognition is given to diversity (Rios, 2018) including minority interest groups such as women's rights and ecoconscious groups along with other single-issue lobbies.

Politically, a very conspicuous worldwide trend since 1990 has been the demise of the once omnipotent nation-state that has found its power base diminished by the forces of globalisation, the neo-liberal economic revolution, the empowerment of civil society, and by individual subjects brought about by, inter alia, the ICT revolutions (Bauman, 2017). In the power vacuum left by the downsizing of the nation-state, the locus of power in modern society has moved in two opposing directions - upwards toward more supra-national structures (like, for example, the European Union) and international structures (such as the International Monetary Fund and the World Bank), and downwards towards sub-national and local structures extending right down to the individual.

A further political trend is democratisation, which has also made its presence felt on the globe since 1990. From 1990 to the mid-2000s, the number of countries in the world that could be classified as democratic had increased from 35 to 100 (Fukuyama, 2019). Finally, on the political scene, the Creed of Human Rights, embraced by an increasing number of governments, has arisen, and has assumed the developing status of a new moral global order (Prozesky, 2018).

In this article, we argue that these trends not only create a new world, but also have a direct impact on crucial areas such as education. The call comes for education praxis in institutions of education, for research in education, and for teacher education to be rethought and recast. As mentioned earlier, the revisions required can be summarised in the three keywords of relevance, responsiveness, and authenticity. First, we will clarify these three keywords, in 
terms of their lexical meaning, before elucidating their meaning for education praxis, for education scholarship, and for teacher education in the context of such a new global order. Since an understanding of these concepts is absent or at least deficient in education praxis and scholarship as it manifests itself today, we have eschewed whatever meanings are attached to these terms in education-discipline dictionaries, and have turned, rather, to the general use of these terms in society.

\section{Conceptual clarification: relevant; responsive; authentic}

\section{Relevance}

The commonplace understanding of what is meant by relevance includes the notion of its applicability to what is happening in the immediate context of its use. Given that education uses a large part of the government budget of all countries in the world and that in many it is the single biggest item of government expenditure, and given that often large portions of household income are allocated to the education of children (highlighted by the fact that this portion often correlates negatively with household income), the question regarding the relevance of education is a legitimate one. The lexical definition of "relevance" includes reference to "to what is happening." Drawing heavily on the depiction of the set of contemporary societal trends outlined above, we investigate, later in this article, the implications of this for education praxis, education research, and teacher education.

\section{Responsive}

To be responsive is to express a reaction to something or someone by saying or doing something. The connotations of responsiveness include speed and positivity along with improvement. Once again, the priority afforded to education by individual people, families, the government, and society, as is clear from, inter alia, the budgetary allocations referred to above, means that mere relevance (a word used frequently in public and scholarly discourse about education) is not enough. Such relevance should be complemented by responsiveness.

\section{Authentic}

To be authentic is to be true and genuine and without dissimulation or pretence. We focus on the meaning of responsiveness in education, education scholarship, and teacher education later in this article. and suggest that however relevant education praxis and scholarship and teacher education may be with regard to responsiveness and authenticity, this is not enough; these shortcomings need to be addressed.

\section{Education praxis}

Before investigating the relevance, responsiveness, and authenticity of education praxis in the world of today, the concept of education needs to be clarified, too. In this article, we use the working definition of education according to the United Nations Educational, Scientific and Cultural Organisation's (UNESCO) use since UNESCO was created collectively by members 
of the global community expressly for the promotion and expansion of education. For UNESCO (2011. p. 1),

- Education includes "deliberate activities involving some form of communication intended to bring about learning."

- Communication is defined as "a relationship between two or more persons or an inanimate medium and persons, involving the transfer of information (messages, ideas, knowledge, strategies, etc.). Communication may be verbal or non-verbal, direct or face-to-face or indirect or remote, and may involve a wide variety of channels and media."

- Learning is described as "individual acquisition or modification of information, knowledge, understanding, attitudes, values, skills, competencies or behaviours through experience, practice, study or instruction."

We use these as working definitions (which are by no means above criticism) in this article.

There are many stakeholders involved in taking up the challenge of making education more relevant, responsive, and authentic on a national and international level. Before the specific role and responsibilities of scholars in education can be conceptualised, the habitus of education and, therefore, the working space of scholars and researchers, needs to be clarified.

According to the best available evidence, schools appeared for the first time in Egypt and Mesopotamia by about $3000 \mathrm{BC}$. Their main purpose was the training of scribes since this was shortly after the invention of writing (Bowen, 1982). Few scholars, as far as we know, have thus far attempted to explain the origin of schools. However, based on impact, it is worth tabling two theories, that of Cohen (1970) and the more recent theory of Gray (2013). According to Cohen, schools originated in what he calls "civilisation states" (1970, p. 1) formed from the amalgamation of smaller political entities. Such states, for example Mesopotamia, Ancient Egypt, China, and Ancient Athens, had to train an elite or a bureaucracy, and among the members of this elite, loyalties to smaller political, geographical, and social units had to be suppressed and replaced by loyalties towards the new, larger state. For this purpose, schools were called into existence in order to cultivate loyalty and identification with the state. Cohen (1970) has also documented the rise of public systems of national education from the 19th century in the newly created nation-states of the world, which had the same goal.

Whereas Cohen identifies a political motive for the creation of schools, Gray (2013) offers an economic rationale. According to him, in the centuries after the agricultural revolution had commenced, a new type of individual was needed. The person of the hunting-and-gathering phase of economic development, who could go about autonomously and at leisure, was at odds with the requirements of an agricultural economy that called for a disciplined worker, and schools were created to stifle the will and instincts that yearned for freedom. The goal was to produce docile workers who were submissive to the dictates of society. 
There is a high probability that both these theories contain some elements of truth concerning the origin of schools. Such a model, in which schools function as a straightjacket coercing students and an education system that produces thousands of children as similar cookie-cutter individuals, is out of step with the demands of the present context. It is beyond the scope of this article for us to offer an exhaustive comparison of the contemporary school against Cohen's or Gray's model, but we do claim that in this day and age, the school still bears strongly the imprint of these templates upon which it was historically predicated. Eminent scholars, such as Welch (1991), have argued that the school still functions primarily as a legitimising agent of the political order of the day. Furthermore, it seems impossible to advocate changes in schools if the methods and programmes we use to train teachers are not also critically evaluated and ultimately adapted.

\section{Teacher education}

The teaching profession is of very recent origin. At the inception of schools in about 2500 $\mathrm{BC}$, it was the clergy, from priest-scribes in Mesopotamia to monks and bishops in medieval times and after, who doubled as educators. The first sign of teaching as a stand-alone profession appeared in the aftermath of the Thirty Years War (1618-1648), when returning soldiers, who were too badly wounded to resume agricultural work, were employed as teachers. The Polish claim that the Seminary in Cracow, founded in 1783, was the first institution dedicated exclusively to the education of teachers. The general historical evolution of teacher education worldwide was initially school-based, and students were considered to be informal apprentices. During the next phase, normal colleges opened in many places, and subsequently, teacher training colleges delivered secondary school teachers to provide for the needs of the country. It was only at a later stage that training was also developed for primary school educators. Currently, universities are assigned the responsibility of teacher education. There has also been a gradual extension of the duration of teacher education at universities. First, a bachelor's degree sufficed, but Finland set the trend for requiring a master's degree, and the European Higher Education Area is following suit (at least as far as the minimum requirement for teachers in upper secondary schools is concerned). Even countries as far away from Finland as Malaysia have been affected by the Finnish example.

A number of models for teacher education programmes exist. In scholarly literature, the seminal work that steered the global discussion on the content and structure of teacher education programmes surely is the highly cited model of Shulman (1987), published in the Harvard Educational Review in 1987. At the time of writing, January 2019, Google Scholar had 19, 487 citations of this publication. Shulman identifies seven categories of knowledge with which he argues teacher education programmes should equip teacher students.

- content knowledge

- general pedagogical knowledge

- curricular knowledge

- pedagogical content knowledge (a term that Shulman developed to describe knowledge required to teach a particular subject or field) 
- knowledge of learners and their characteristics

- knowledge of educational ends, purposes, values, and their philosophies and historical grounds

- knowledge of educational contexts

Despite the lofty parameters that Shulman set for a scholarly discourse on the curricula of teacher education programmes, the fact is that the trend in recent decades worldwide has been for teacher education to change from schooling in the basic foundational disciplines of education (such as philosophy of education, history of education, educational psychology, sociology of education, and the like), to training in a set of competencies regarded as necessary for teaching, much like the training of technicians (Altbach, 1991; Schweisfurth, 1999). While some scholars, such as Zeichner (2013), endorsed this trend, there are several other schools of thought on the format and content of teacher training. Authors such as Sykes (2004) and Darling-Hammond and Bransford (2005) plead for a professional education for teachers that is based on the conceptualisation of teaching as a profession. Two of the distinguishing traits of such a profession is the possession of a body of advanced knowledge not commonly held by people outside of the profession and the practice of not relying on standard answers but on, rather, a specialised body of expert knowledge for making decisions. Others, such as Connell (2009), consider such a model as unnecessarily costly and call for fast training of teachers according to a standardised script that they can deliver when teaching in schools. After a few years, when a new script is needed or implemented, these teachers can be dismissed quickly and be replaced by others trained in a similar fashion. In South Africa, the policy directives of the early 2000s on teacher education, which followed the introduction of Outcomes-Based Education in the country, gave additional impetus to this utility trend in teacher education (Wolhuter, 2010).

Given all the strains of thought regarding teacher education, it is clear that a recasting and a rethinking is needed, on both the local and the global front. Such a reconceptualisation should address and reverse not only the increasingly pragmatic slant in teacher education programmes, but should also prepare teachers for a new teaching-learning praxis and for the exigencies of a new era in which the mechanistic application of techniques of the past will not do, but in which student teachers should engage with a body of education scholarship with rigour and depth worthy of that name.

\section{Rethinking education and schooling}

In view of the nascent society taking form in the early 21 st century, as described above, we suggest the following ten radical changes in schools and education praxis.

1. The fundamental ethos of the school should change from the foisting down of what hegemonic society dictates to creating a space in which creativity, independence, and autonomy of the educand can grow and be realised. While the agricultural or industrial economy required a submissive worker, a knowledge economy, the Creed of Human Rights, and a democratic society call for a creative person who is given the required space 
in which his or her autonomy can flourish. Education institutions, schools in particular, should be responsive to the call from society for education for creativity (Henriksen et al., 2018) and thus also be authentic, in bringing about learning, in the fullest sense of the word according to the UNESCO definition of education proffered above.

2. Related to this, the school needs to be redesigned to give each individual scope for the promotion of his or her own capabilities (in the sense of the capabilities theory of Sen (2010), Nussbaum (2011), and others) instead of affording the privilege of (rather narrowminded) socialisation as a student exclusively to a selected few. Research in South Africa has shown that individual differentiation of learners by teachers is much wanting (De Jager, Coetzee, Maulana, Helms-Lorenz, \& Van de Grift, 2017). The overcrowding of classrooms results in teachers' being frustrated that they cannot give individualised attention to each child (Muthusamy, 2015), but in the US the Report by Colangelo, Assouline, \& Gross et al. (2004) identified lack of individualisation as eventually costing the country dearly in terms of unrealised potential. Through the capabilities approach, people are given freedom, and the approach is built on the moral imperative that a person can experience wellness through having opportunities or capabilities to do and be what he or she values. Therefore, denying such freedom or limiting anyone's capacity is morally wrong (Nussbaum, 2011; Sen, 2010), while opening space for such freedom renders the school experience relevant and responsive to the needs of each educand.

3. In the public vernacular, teaching and learning have traditionally been considered as two separate topics, while in the scholarly discourse, the change has been brought about by combining the two topics of teaching and learning into one. This is evident in the name of the field of teaching-learning scholarship. Although a new trend seems to be emerging that refers to learning-teaching (that is, privileging the learning side of the coin), schools still remain mostly teacher- or teaching-centred. This is true even of model education systems such as that in Finland (Andrews, 2013; Lehtinen, 2004). In South Africa, there is evidence of education in classrooms still being extremely teacher-centred (Lehesvuori, Rammarain, \& Viiri, 2018). An effort, therefore, needs to be made to shift the perspectives, policies, and practices of schools from teaching and learning to learningteaching, ensuring a more authentic learning experience for the educand.

4. There is ample evidence to suggest that schools and educational institutions in South Africa, and even worldwide, may not be living up to expectations. Despite vast amounts of public resources invested in education, statistics related to internal efficiency and assessment results are distressing. In the case of South Africa, internal efficiency is measured by the national matric examination results. In 2018, 512,700 candidates sat for this examination in South Africa - only $51 \%$ of the 1,002,500 learners who entered Grade 1 in 2007, 12 years earlier. These disturbing statistics are, however, not the picture that is painted by the national government as it proclaims growing success with a pass rate of $78,2 \%$. More evidence to suggest that such a pass rate is not a valid and true reflection of the state of education in South Africa can be seen in the poor achievement of learners in international test series, such as the International Programme of Student Assessment (PISA) and the International Association for the Evaluation of Educational Achievement (IEA). We should be asking if the focus on, and concern about, the allocation of public funding and resources, matric results, and other national testing might be overshadowing 
the true purpose of education in South Africa. Education should be the main instrument towards economic growth and be a valuable tool used to instill democratic values in citizens, and open possibilities for the educand. A successful education system will then do more than merely produce good academic matric results and will produce learners with the necessary skills to transform society so as to establish one based on a value system that includes, for example, equality, non-sexism, and non-racism. Despite the fact that these aims are clearly formulated in Education Policy documents, they do not come into fruition through the education taking place in schools in South Africa because, among other factors, these values are not properly integrated in curricula (Botha, Joubert, \& Hugo, 2016).

5. In view of the diminishing place of the nation-state and the number of compelling global forces shaping 21st-century society, citizenship education in schools that are still trapped within the parameters of the nation-state (Torres, 2017), should be replaced or at least strongly complemented by global citizenship education. In South Africa the preoccupation with imperatives such as the decolonisation of education and the use of education to promote national cohesion in society - all valid discourses - has distracted attention from the equally valid consideration of cultivating a global mindset.

Furthermore, Solomon and Fataar (2011) have expressed doubt in the capacity of schools in South Africa to effect any form of civic education because there are just too many societal and education system contextual factors militating against this pursuit of schools; these doubts are shown to be valid by the empirical research of Botha et al. (2016). However, to be relevant and responsive to the needs of contemporary society, education in South Africa should remedy this lack of performance, and scholars of education should place this goal on their research agenda.

6. In view of the stark ecological crisis staring us in the face, to the point of threatening the survival of humanity and the planet, education for sustainable development should be prioritised and should permeate the entire school curriculum and programme. While the international community did, as part of the Sustainable Development Goals, formulate the Incheon Declaration in 2015, spelling out a vision for education in the world by 2030 (UNICEF, 2015), the relationship between these goals and sustainable development should be explicated and this should inform education reform worldwide. As Fourie (2018) has argued, South Africa, too, should align its societal plan (including its education one) with the global Sustainable Development Goals, in order to set in place an education system responsive to the compelling needs experienced now by the global community.

7. The 21st-century societal context, with quintessential features such as the technological revolution and the nascent knowledge economy, calls for a reconceptualisation of education. This requires a restructuring of education programmes and institutions so that education is no longer a once-off process in the early stages of life, but a life-long one (Ogunleye, 2014).

8. Although this was not the case a generation ago, information is now freely available on a plethora of electronic platforms, making the mere transmission of knowledge the main driver of educational institutions increasingly obsolete. Schools and educational institutions should emphasise, rather, the teaching of critical skills needed to manage, 
analyse, and evaluate large amounts of data and items of information. In this manner, learners and students will no longer be only the recipients of knowledge, and teachers the facilitators of knowledge, but both parties will become equipped to, and confident in, creating new knowledge. This is especially pertinent to the fourth industrial revolution the world is experiencing, as well as in times when the promotion of indigenous knowledge and decolonisation are topical issues (Fataar, 2018).

9. The exigencies of the 21 st century forced the philosophy of multicultural education to be superseded by that of intercultural education. While many different definitions have been attached to this term, in this article, we use the meaning attached to it by Markou (1997, p. 1) who explains the four principles of intercultural education thus:

- Education with empathy, which means showing a deep understanding for others while attempting to understand their unique position.

- Education with solidarity that directs an appeal towards the cultivation of a collective conscience and the promotion of social justice.

- Education with intercultural respect.

- Education with ethicist thinking that assumes the presence of continuous dialogue.

10. Recent turmoil on South African university campuses (see Habib, 2019) underlines the need for the development of intercultural dialogue and intercultural education.

11. Assessment practices in schools and other institutions of education should undergo a change; the emphasis should move from norm-referenced and criterion-referenced assessment to ipsative assessment. See Bansilal and Mjobi (2012) and Howe (2012) for criticism of the ways in which norm-referenced and criterion-referenced assessment function in the present South African education system. Ipsative assessment compares a student's performance to his or her own previous work rather than seeking to measure his or her performance against either external criteria and standards or the performance of peers. In this manner, the aim of assessment is geared towards a personal best rather than towards a competition against other students, and this ensures that an authentic education is provided to each learner.

\section{Education theory and scholarship}

The task of guiding research and implementing the abovementioned changes in schools and educational praxis falls upon members of the scholarly field of education. Before such changes can become a reality in the South African and global education system, a vast amount of valid and reliable research needs to be done. Many valuable projects, like, for example the research done by De Jager et al. (2017) cited above, have already been completed and are on the way. The challenges facing South African and global education scholarship can also be summarised as is the case with education praxis, by a three-part descriptor - the need to become relevant, responsive, and truly authentic. Against these needs stand accusations of a lack of academic rigour in education research, challenges in terms of the structure of educational knowledge and academic publications, and a lack of original theoretical frameworks designed specifically for education (Furlong \& Lawn, 2011). There has been a long-standing accusation against scholars of education that much of their 
scholarship lacks academic rigour, thereby reducing education scholarship to the status of a pseudoscience or to being seen as inferior to other fields of research. This allegation was first made very explicitly by Labaree in a journal article in 1998 that was later developed into a book in 2004. This claim was also repeated by critics in South Africa, in, for example, a special issue of the journal Perspectives in Education (34(1), 2016). Furthermore, there is a problem with the structuring or packaging of education knowledge. Two recently edited volumes on the structure of education knowledge (Whitty \& Furlong, 2017; Zapp, Marques, Powell, Biesta, \& Helgetun (2018) highlight how such structures differ from one national setting to the other and how each is influenced and determined by national-contextual forces, rather than by disciplinary-logical considerations. In South Africa, an analysis by van der Westhuizen, van der Walt, and Wolhuter (2011) of reviewers' reports of submissions to the South African Journal of Education revealed that one of the major reasons for the rejection of manuscripts was that authors failed to place their research within a relevant and strong theoretical framework. In a further movement, the non-accumulative nature of much education research has been noted locally (Deacon, Osman, \& Buchler, 2009), as well as internationally (Furlong, 2013).

A final problem threatening the various fields of education research is the lack of autochthonous theory. The major theoretical frameworks used by most researchers have been developed by scholars in fields other than education and with no background in this discipline. In comparative and international education, for example, the pioneers of basic theoretical frameworks and most often used paradigms were developed by scholars from fields other than education, like, for example, economic reproduction by economists Sam Bowles and Harry Gintis in 1976, the dependency theory by economist André Gunder Frank in 1966, cultural reproduction by sociologists Pierre Bourdien and J. G. Passeron in 1977 in 1961, and the human capital theory by economist Theodor Schultz in 1961. One problem is that such theoretical frameworks do not make central the dynamics of the symbiosis of teaching-learning processes in educational institutions if we take into account the definition of education offered above, and this hampers the value of these frameworks to guide education praxis and contribute towards the quest to make education on all three planes of schools, teacher training, and scholarly research more relevant, responsive, and authentic.

\section{Conclusion}

The most recent South African policy directive on teacher education from the Department of Higher Education and Training, The revised policy on the minimum requirements for teacher education (2015), known as the MRTEQ document, with its re-appreciation of the place of foundational disciplines of education, offers the opportunity for a re-design of teacher education programmes in South Africa, thus moving away from the dangers of an overly utilitarian approach to this area of study. Given the teaching-research symbiosis at most universities, such an adjustment in teacher education programmes may well also open the door to a concomitant quantum leap in education scholarship in not only elevating it in terms of rigour and depth but also gearing it to the exigencies of the unfolding 21 st century. This 
would mean that teacher education programmes and education praxis will be supplied with the scientific or scholarly underpinnings needed to turn teachers into professional educators.

Papers presented at the 2018 Annual SAERA Conference provided much evidence that echoes these thoughts. It is our wish that the papers in this volume, each zooming in on one theme, that unpack this notion of the restructuring and redesign of education praxis, teacher education, and the field of education scholarship, will prove to be an incentive for the scholarly community of South Africa (and beyond) to rise to this global challenge.

\section{References}

Altbach, P. G. (1991). Trends in comparative education. Comparative Education Review, 35, 491-507.

Andrews, P. (2013). Finnish mathematics teaching from a reform perspective: A video-based case-study analysis. Comparative Education Review, 57(2), 189-211.

Bansilal, S. \& Mjoli, B. (2012) What can we learn from the KZN ANA results? SA-eDUC Journal 9, (2), n.p. Retrieved from https://pdfs.semanticscholar.org

Bauman, Z. (2017). A chronicle of crisis: 2011-2016. London, UK: Social Europe.

Benjamin, H. R. W. (1939). The Saber tooth curriculum. New York, NY: McGraw Hill.

Botha, A., Joubert, I., \& Hugo, A. (2016). Children's perception of democratic values: Implications for democratic citizen education. South African Journal of Childhood Education, 6(1), 1-8. Retrieved from https://sajce.co.za/index.php/sajce/article/view/343/412

Bowen, J. (1982). A history of Western education (Vol. I). London, UK: Methuen.

Brezinka, W. (1981). The limits of education. Logos, 1, 2-5.

Cohen, Y. (1970). Schools and civilization states. In J. Fischer (Ed.), The social sciences and the comparative study of educational sciences (pp. 1-20). Scranton, PA: International Textbook Co.

Colangelo, N., Assouline, S. G., \& Gross, M. U. M. (2004). A nation deceived: How schools hold back America's brightest students (Vols. 1-2). Iowa City, IA: The Connie Belin $\&$ Jacqueline Blank International Center for Gifted Education and Talent Development.

Connell, R. (2009). Good teachers on dangerous ground: Toward a new view of teacher quality and professionalism. Critical Studies in Education, 50(3), 213-259.

Darling-Hammond, L. D., \& Bransford, J. (Eds.). (2005). Preparing teachers for a new century. San Francisco, CA: Jossey Bass. 
Deacon, R., Osman, R., \& Buchler, M. (2009). Audit and interpretive analysis of education research in South Africa: What have we learned? Research report submitted to the National Research Foundation.

De Jager, T., Coetzee, M. J., Maulana, R., Helms-Lorenz, M., \& Van de Grift, W. (2017). Profile of South African Secondary-School Teachers' Teaching Quality: Evaluation of teaching practices using an observation instrument. Educational Studies, 43(4), 410-429.

Department of Higher Education and Training. (2015). Revised policy on the minimum requirements for teacher education. Pretoria, RSA: Government Printer.

Dorling, D. (2013). Population 10 Billion: The coming demographic crisis and how to survive it. London, UK: Constable.

Fataar, A. (2018). Decolonising education in South Africa: Perspectives and debates. Education Research for Social Change, 7, vi-ix.

Fourie, W. (2018, March 27). How South Africa can align its development plan with the SDGs. The Conversation. Retrieved from http://theconversation.com/how-southafrica-can-align-its-development-plan-with-the-sdgs-93302

Friedman, T. L. (2009). Hot, flat and crowded: Why the world needs a green revolution. London, UK: Penguin.

Friedman, T. L. (2016). Thank you for being late: An optimist's guide to arriving in an age of accelerations. New York, NY: Fallon, Strauss \& Giroux.

Fukuyama, F. (2019, January, 4-10). Identity politics is about our quest for recognition. Mail \& Guardian. Retrieved from https://mg.co.za/article/2019-01-04-00-identity-politicsis-about-our-questfor-recognition

Furlong, J. (2013). Education: An anatomy of the discipline. London, UK: Routledge.

Furlong, J., \& Lawn, M. (Eds.). (2011). Disciplines of education: Their role in the future of education research. London, UK: Routledge.

Gray, P. (2013). Free to learn: Why unleashing the instinct to play will make our children happier, more self-reliant, and better students for life. New York, NY: Basic Books.

Gribbin, J. (2006, November 3). The meaning of the 21 st century by James Martin. The Independent. Retrieved from https://www.independent.co.uk/artsentertainment/books/reviews/the-meaning-of-the-21st-century-by-james-martin422636.html

Habib, A. (2019). Rebels and rage: Reflecting on \#fees must fall. Jeppestown, RSA: Jonathan Ball. 
Harari, Y. N. (2011). Sapiens: A brief history of humankind. London, UK: Vintage.

Harari, Y. N. (2015). Homo deus: A brief history of tomorrow. London, UK: Harvill Secker.

Harari, Y. N. (2018). 21 lessons for the 21 st century. London, UK: Jonathan Cape.

Henriksen, D., Henderson, M., Creely, E., Ceretkova, S., Cernechova, M., Sendova, E., Sointu, E. T \& Tienken, C. H. (2018). Creativity and technology in education: An international perspective. Technology, Knowledge and Learning, 23(3), 409-424.

Howe, M. L. (2012). Hyphenated validity: Comparability of assessment protocols in English language between two examination boards. SA-eDUC, 9(2), 1-10.

Ireland, S. (2010, September 28). Martin Rees: "We should not attach any weight to what Hawking says about god." The Independent. Retrieved from https://www.independent.co.uk/news/people/profiles/martin-rees-we-shouldnt-attachany-weight-to-what-hawking-says-about-god-2090421.html

Kirche, A. (2015). H. G. Wells on education. Retrieved from https://blogs.bl.uk/science/2015/09/hg-wells-education.html

Labaree, D. F. (1998). Educational researchers: Living with a lesser form of knowledge. Educational Researcher, 27(8), 4-12.

Labaree, D. F. (2004). The trouble with Ed schools. New Haven, CT: Yale University Press.

Lehesvuori, S., Ramnarain, U., \& Viiri, J. (2019). Challenging transmission modes of teaching in science classrooms: Enhancing learner-centredness through dialogicity. Research in Science Education, 48(5), 1049-1069.

Lehtinen, E. (2004). Education system in the changing Finnish society. Helsinki, EE: Sitra.

Lutz, W., \& Klingholz, R. (2017). Education first! From Martin Luther to sustainable development. Stellenbosch, RSA: Sun Media.

Markou, G. (1997). Introduction to intercultural education. Athens, GD: Pappas Bros.

Martin, J. (2006). The meaning of the 21st century: A vital blueprint for ensuring our future. London, UK: Penguin.

Mortimer, I. (2015). Human race: 10 centuries of change on Earth. New Delhi, IN: Random.

Nussbaum, M. C. (2011). Creating capabilities: The human development approach. Cambridge, UK: Belknap Press. 
Ogunleye, J. (2014). Concepts, recognition, validation of skills and support for lifelong learning: A European perspective. In H. J. Steyn \& C. C. Wolhuter (Eds.), The education system: A comparative education perspective. Noordbrug, RSA: Keurkopie.

Piketty, T. (2014). Capital in the 21st century. London, UK: Random House.

Prozesky, M. (2018). Tomorrow's ethics in a globalizing world. Journal for the Study of Religion, 31(1), 307-309. http://dx/doi.org/10.17159/2413-3027/2018/v31n1a17

Rios, F. (2018). The legacy and trajectories of multicultural education: Recognition, refusal, and movement building in troubling times. Multicultural Education Review, 10(3), $165-183$.

Schram, S. F. (2015). The return of ordinary capitalism: Neoliberalism, precarity, occupy. Oxford, UK: Oxford University Press.

Schwab, K. (2016). The fourth industrial revolution. New York, NY: Currency.

Schweisfurth, M. (1999). Resilience, resistance and responsiveness: Comparative and international education at United Kingdom universities. In R. Alexander, P. Broadfoot $\&$ D. Phillips (Eds.), Learning from comparing: New directions in comparative education research. Contexts, classrooms and outcomes (Vol. 1, pp. 60-79). Oxford, UK: Symposium Books.

Shulman, L. (1987). Knowledge and teaching: Foundations of the new reform. Harvard Educational Review, 57(1), 1-22.

Sen, A. (2010). The idea of justice. London, UK: Penguin Books.

Solomon, I., \& Fataar, A. (2011). A conceptual exploration of values education in South Africa in the context of schooling in South Africa. South African Journal of Education, 31(2), 224-232

Sykes, G. (2004). Cultivating teacher quality: A brief for professional students. In F. Hess, A. Rotherham \& R. Walsh (Eds.), A qualified teacher in every classroom? (pp. 177200). Cambridge, MA: Harvard Education Press.

Toffler, A. (1970). Future Shock. New York, NY: Bantam.

Torres, C. A. (2017). Theoretical and empirical foundations of critical global citizenship education. New York, NY: Routledge.

UNESCO. (2011). ISCED: International standard classification of education. Retrieved fromhttp://uis.unesco.org/sites/default/files/documents/international-standardclassification-of-education-isced-2011-en.pdf 
Unger, R. M. (2019). Rethinking the knowledge economy. American Affairs, 3(2), 3-24.

UNICEF. (2015). Education 2030: INCHEON Declaration: Towards inclusive and equitable quality education and lifelong learning for all. New York, NY: UNICEF.

van der Westhuizen, P. C., van der Walt, J. L., \& Wolhuter, C. C. (2011). How an analysis of reviewers' reports can enhance the quality of submissions to a journal of education. South African Journal of Education, 31(1), 1-4.

Welch, A. Q. (1991). Knowledge and legitimation in comparative education. Comparative Education Review, 35(3), 508-531.

Whitty, G., \& Furlong, J. (Eds.). (2017). Knowledge and the study of education: An international exploration. Oxford, UK: Symposium Books.

Williams, S. (2019). Decline of the family and its consequences. Retrieved from https://www.austriancenter.com/decline-of-the-family-and-its-consequences

Wolhuter, C. C. (2010). Teacher training in South Africa: Reforms and challenges. In K. G. Karras (Ed.), International handbook on teacher education world wide (Vol. 1, pp. 861-875). Athens, GD: Atrapos.

World Bank. (2016). World development indicators 2016. Washington, DC: The World Bank Group.

World Bank. (2018). World development indicators. Retrieved from https://data.worldbank.org/indicator/NY.GDP.MKTP.CD?view=chart

World Bank. (2019). The Changing Nature of Work. Washington DC: The World Bank.

Zapp, M., Marques, M., Powell, J. J. W., Biesta, G., \& Helgetun, J. B. (Eds.). (2018). European educational research (re)constructed: Institutional change in Germany, the United Kingdom, Norway and the European Union. Oxford, UK: Symposium Books.

Zeichner, K. (2013). Two visions of teaching and teacher education for the twenty-first century. In X. Zhu \& K. Zeichner (Eds.), Preparing teachers for the twenty-first century (pp. 3-19). Dordrecht, NL: Springer. 